\title{
Periplasmic cyclic 1,2- $\beta$-glucan in Brucella spp. is not osmoregulated
}

\author{
Gabriel Briones, ${ }^{1}$ Nora Iñón de lannino, ${ }^{2}$ Marcelo Steinberg ${ }^{2}$ and \\ Rodolfo A. Ugalde ${ }^{2}$ \\ Author for correspondence: Nora Iñón de Iannino. Tel: +54 1863 4011/19. Fax : +54 18652246 . \\ e-mail: norai.fc@iris.iib.uba.ar
}

1 Comisión Nacional de Energía Atómica, División Agropecuaria, Centro Atómico Ezeiza, Buenos Aires 1405, Argentina

2 Instituto de Investigaciones

Bioquímicas, Fundación Campomar, Avda. Patricias Argentinas 435, Buenos Aires 1405, Argentina

\begin{abstract}
Biosynthesis of periplasmic cyclic 1,2- $\beta$-glucans in Brucella ovis strain RE0198 and B. abortus strain $\mathbf{S 1 9}$ was found to be carried out by membrane-bound enzymes that use UDP-glucose (UDP-GIC) as donor substrate. Contrary to what happens in species of the genera Agrobacterium and Rhizobium, the accumulation of the reaction products in Brucella appeared not to be osmotically regulated. Incubation of permeabilized cells with UDP-[ $\left.{ }^{14} \mathrm{C}\right] \mathrm{GIc}$ led to the formation of soluble neutral cyclic 1,2- $\beta$-glucans and $\left[{ }^{14} \mathrm{C}\right]$ glucoselabelled glucoproteins. PAGE of pulse-chase experiments carried out with permeabilized cells showed that the molecular mass of the labelled protein was indistinguishable from Agrobacterium tumefaciens A348 and Rhizobium fredii USDA191 glucoproteins known to be intermediates in the synthesis of cyclic glucans. Brucella total membrane preparations were less efficient than permeabilized cells in the formation of cyclic glucan; this was attributed to defective cyclization. Accumulation of protein intermediates having oligosaccharides of high molecular mass that were not released from the protein was observed after chase with $2 \mathrm{mM}$ UDP-Glc. This defect was not observed when permeabilized cells were used as enzyme preparation, thus suggesting that in Brucella a factor(s) that was lost or inactivated upon the preparation of membranes was required for the effective regulation between elongation and cyclization reactions.
\end{abstract}

Keywords: Brucella, cyclic 1,2- $\beta$-glucan, osmoregulation

\section{INTRODUCTION}

The family Rhizobiaceae includes the genera Agrobacterium and Rbizobium. Bacteria from both genera synthesize cyclic 1,2- $\beta$-glucans (York et al., 1978; Zevenhuizen \& Neerven, 1983; Hisamatsu et al., 1983). Many roles have been assigned to these polysaccharides. For instance, several studies have shown that in the family Rhizobiaceae the biosynthesis of cyclic $\beta$-glucans is osmotically regulated and thus a role for the polysaccharides in hypo-osmotic adaptation has been suggested (Miller et al., 1986; Dylan et al., 1990; Breedveld et al., 1990; Tully et al., 1990; Cangelosi et al., 1990; Zorreguieta et al., 1990). In contrast, studies carried out with $R$. meliloti and $A$. tumefaciens mutants $(n d v A / n d v B$ and $c h v A / c h v B$, respectively) provided

Abbreviations: BBS, Brucella broth serum medium; TCA, trichloroacetic acid. substantial evidence of their involvement in bacteriaplant interactions (Puvanesarajah et al., 1985; Douglas et al., 1985; Dylan et al., 1986; Geremia et al., 1987; Iñón de Iannino \& Ugalde, 1989). Genes chvB and chv $A$ encode 235 and $75 \mathrm{kDa}$ inner-membrane proteins involved in the synthesis and secretion, respectively, of cyclic 1,2- $\beta$-glucans (Zorreguieta \& Ugalde, 1986; Iñón de Iannino \& Ugalde, 1989; Cangelosi et al., 1989). Mutants in the $n d v B$ locus induce the formation of pseudonodules in alfalfa (Dylan et al., 1986; Geremia et al., 1987). In Rhizobium and Agrobacterium, cyclic 1,2$\beta$-glucan synthesis proceeds through the formation of a protein intermediate (Zorreguieta \& Ugalde, 1986). Glucose is transferred from UDP-Glc to an unidentified amino acid of the above-mentioned $235 \mathrm{kDa}$ innermembrane protein. After elongation the glucan is cyclized, released from the protein and secreted into the periplasmic space (Zorreguieta \& Ugalde, 1986; Iñón de Iannino \& Ugalde, 1989). Williamson et al. (1992) demonstrated that the size distribution of cyclic $1,2-\beta-$ 
glucan products depends on competing elongation and cyclization reactions, thus suggesting that both processes are interrelated.

The role of cellular polysaccharides in bacteria-cell interactions and pathogenesis is well known (Finan et al., 1985; Leigh et al., 1985; Whatley et al., 1976; Abe et al., 1982; Puvanesarajah et al., 1985). Brucella spp. are animal pathogens that produce a chronic disease characterized by recurrent fever in humans, abortion in ungulates and persistence of the pathogen inside phagocyte cells of the reticuloendothelial system (Smith \& Ficht, 1990). Brucella lipopolysaccharide is highly antigenic and induces a specific antibody response (Moreno et al., 1981b). Rough mutants of B. abortus are defective in the synthesis of the $\mathrm{O}$ polysaccharide or the core region and cases have been described in which such mutants have lost virulence (Reeves, 1995). B. ovis and $B$. canis isolated from infected animals are, however, pathogenic rough mutants. In Brucella interest has also been given to another polysaccharide, polysaccharide $B$ (poly B). B. abortus-infected animals have been reported to produce antibodies that precipitate poly $\mathrm{B}$, while serum from S19-vaccinated animals does not. It has been proposed that poly B might be useful in differentiating vaccinated from infected animals (Cherwonogrodzky et al., 1990; Moreno et al., 1981a). More recently, however, Bundle et al. (1988) purified and characterized poly $\mathrm{B}$ and demonstrated that it was a mixture of a non-immunogenic family of cyclic $1,2-\beta$ glucans and the $\mathrm{O}$ chain of the lipopolysaccharide that carried the serological reactivity.

Brucella, Rhizobium and Agrobacterium belong to a very close taxonomic group according to their $16 \mathrm{~S}$ rRNA sequences (Triplett et al., 1994; De Lay, 1987) and individual species of all these genera have been shown to produce cyclic 1,2- $\beta$-glucans (Hisamatsu et al., 1983; Bundle et al., 1987, 1988). In Agrobacterium and Rhizobium these glucans are required for virulence and nodule invasion, respectively. In Brucella, however, the biosynthesis and the possible role in pathogenesis of this periplasmic polysaccharide have not yet been studied. No homologies of Brucella genome with $c h v B / c h v A$ or $n d v B / n d v A$ genes have been reported so far. In this paper we demonstrate that in B. ovis and B. abortus, contrary to what happens in species of the genera Agrobacterium and Rhizobium, the accumulation of periplasmic cyclic $1,2-\beta$-glucan is not osmoregulated. However, although the biosynthesis of the polysaccharide proceeds, as in the other mentioned species, through a glucoprotein intermediate, the cyclization reaction requires a factor(s) in the Brucella spp. examined.

\section{METHODS}

Bacterial strains and growth conditions. Brucella ovis strain REO198 and the attenuated vaccine strain B. abortus S19 were used. Both strains were obtained from the Centro Panamericano de Zoonosis, Buenos Aires, Argentina. Cells were grown at $37^{\circ} \mathrm{C}$ in a rotary shaker (200 r.p.m.) in Brucella broth medium (BB, Difco). For growing B. ovis, REO198 medium was supplemented with $10 \%$ normal calf serum (BBS, Gibco BRL). For osmotic studies, $200 \mathrm{ml} \mathrm{BBS}$ medium was supplemented with $0.5 \mathrm{M}$ mannitol, $0.5 \mathrm{M}$ glucose or $0.25 \mathrm{M}$ $\mathrm{NaCl}$.

Gel chromatography, TLC and paper electrophoresis. Gel chromatography was carried out in Bio-Gel P4 columns $(78 \mathrm{~cm} \times 1.8 \mathrm{~cm})$, equilibrated with $0.1 \mathrm{M}$ pyridine acetate buffer, $\mathrm{pH} 5 \cdot 5$. Fractions of $1.5 \mathrm{ml}$ were collected, radioactivity detected in a liquid scintillation counter and sugars quantified by the anthrone-sulfuric acid method (Dische, 1962). TLC was carried out with silica gel-60 plates (Merck) developed three times with 1 -butanol/ethanol/water $(5: 5: 4$, by vol.) as described by Zevenhuizen et al. (1990). Paper electrophoresis was carried out as described previously by Iñón de Iannino $\&$ Ugalde (1993).

Preparation of permeabilized cells and total membranes. Cells from 1 litre cultures grown for $48 \mathrm{~h}$ in 21 flasks were harvested by centrifugation at $8000 \mathrm{~g}$ for $15 \mathrm{~min}$ at $4^{\circ} \mathrm{C}$. Cells were washed with physiological solution $\left(8.5 \mathrm{~g} \mathrm{NaCl}^{-1}\right)$, centrifuged in an Eppendorf centrifuge for $5 \mathrm{~min}$ and pellets stored at $-20^{\circ} \mathrm{C}$ until used. Cell pellets were resuspended in $50 \mathrm{mM}$ Tris/HCl buffer, $3 \mathrm{mM}$ EDTA, pH 8.0, and $2 \mathrm{mM}$ PMSF at approximately $40 \mathrm{mg}$ protein $\mathrm{ml}^{-1}$. Permeabilized cells were prepared by adding $0.1 \%$ Nonidet $P \quad 40$ to resuspended cells just before adding UDP- $\left[{ }^{14} \mathrm{C}\right] \mathrm{Glc}$ to start the enzymic assays. Total membranes were prepared by ballistic disintegration of cells (Moriyon \& Berman, 1982). Cells from 1 litre cultures were harvested, resuspended in $50 \mathrm{mM}$ Tris/ $\mathrm{HCl}$ buffer, $3 \mathrm{mM}$ EDTA, pH 8.0, $2 \mathrm{mM}$ PMSF and broken in a MSK-Braun Cell Homogenizer with $0.25-0.3 \mathrm{~mm}$ glass beads for one cycle of $45 \mathrm{~s}$. After removing glass beads by centrifugation at $3000 \mathrm{~g}$ for $15 \mathrm{~min}$ at $5{ }^{\circ} \mathrm{C}$, supernatants were submitted to centrifugation at $100000 \mathrm{~g}$ for $2 \mathrm{~h}$ at $5^{\circ} \mathrm{C}$. Membrane pellets were resuspended in $50 \mathrm{mM}$ Tris $/ \mathrm{HCl}$ buffer, $3 \mathrm{mM}$ EDTA, $\mathrm{pH} 8 \cdot 0$, at approximately $40 \mathrm{mg}$ protein $\mathrm{ml}^{-1}$ and stored at $-20^{\circ} \mathrm{C}$ until used.

Extraction of cell-associated glucans. Cells from $200 \mathrm{ml}$ cultures were harvested by centrifugation at $10000 \mathrm{~g}$ for $15 \mathrm{~min}$. Pellets were treated with $10 \%$ trichloroacetic acid (TCA). TCA extracts were neutralized with ammonium hydroxide, concentrated and subjected to gel filtration on BioGel P4 columns as described above. Acid hydrolysis, reduction with borohydride, paper chromatography and paper electrophoresis were carried out as described previously (Iñón de Iannino \& Ugalde, 1993) and DEAE-Sephadex chromatography was carried out also as described previously (Iñón de Iannino \& Ugalde, 1989).

Osmotic shock. The zwittergent-lysozyme extraction method was carried out as described by Stabel et al. (1994) with some modifications. Freshly harvested $B$. ovis strain REO198 cells were resuspended in $50 \mathrm{ml} 0.2 \mathrm{M}$ Tris/ $\mathrm{HCl}$ buffer, $\mathrm{pH} 8.0$, with $0.5 \mathrm{M}$ sucrose and $0.25 \% \quad \mathrm{~N}$-alkyl-N,N-dimethylammonio-1-propanesulfonate SB3-16 (Sigma, equivalent to Zwittergent- 316 from Calbiochem). After 5 min of incubation in an ice bath, cells were harvested by centrifugation at $3000 \mathrm{~g}$ for $5 \mathrm{~min}$ and pellets exposed to osmotic shock by addition of $45 \mathrm{ml}$ cold distilled water. A solution of lysozyme (50 mg ml-1 Sigma) was added immediately to the suspension to obtain a final concentration of $50 \mu \mathrm{g} \mathrm{ml}^{-1}$. The cell suspension (total cellular fraction) was shaken for $15 \mathrm{~min}$ at $25^{\circ} \mathrm{C}$ and centrifuged for $15 \mathrm{~min}$ at $12000 \mathrm{~g}$. Supernatants (periplasmic fluid) were freeze-dried and subjected to Bio-Gel P4 chromatography. For malate dehydrogenase, assay aliquots 
were withdrawn from the total cellular fraction before centrifugation, cells were disrupted by freeze-thaw and sonication, centrifuged for $30 \mathrm{~min}$ at $8000 \mathrm{~g}$ and filtered supernatants assayed for enzyme activity as described by Worthington Diagnostic Systems, Inc. (1982). The remaining pellet was treated with $10 \%$ TCA as described above and the TCA extracts were neutralized with ammonium hydroxide and subjected to Bio-Gel P4 chromatography. When osmotic shock was carried out on B. abortus S19 cells, the method described by Stabel et al. (1994) was used with no modifications.

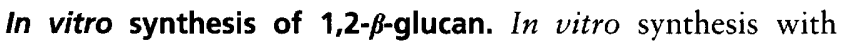
permeabilized cells or total membranes as enzyme sources was carried out as described previously (Iñón de Iannino \& Ugalde, 1993) with the following modifications: the incubation temperature was $37^{\circ} \mathrm{C}$ and 500000 c.p.m. (10.5 GBq mmol $\left.{ }^{-1}\right)$ UDP- $\left[{ }^{14} \mathrm{C}\right] \mathrm{Glc}$ was used in the incubation mixtures.

Purification and characterization of glycopeptides. The TCA precipitates obtained as described previously (Iñón de Iannino \& Ugalde, 1993) were washed twice with $2 \mathrm{ml} 5 \%$ TCA, twice with $2 \mathrm{ml}$ ethyl ether and dried under a nitrogen stream. The TCA precipitates (50000 c.p.m.) were then resuspended in $100 \mathrm{mM}$ Tris $/ \mathrm{HCl}$ buffer, $\mathrm{pH} 7 \cdot 5$, with $10 \mathrm{mM} \mathrm{CaCl}_{2}$ and incubated at $37^{\circ} \mathrm{C}$ with $2 \mathrm{mg}$ protease type XIV from Streptomyces griseus (Sigma) in a total volume of $1 \mathrm{ml}$. After $48 \mathrm{~h}, 1 \mathrm{mg}$ protease was added and the incubations were continued for 2 weeks. TCA $(10 \%)$ was added to stop the reactions and the glycopeptides were recovered from the supernatants after centrifugation for $2 \mathrm{~min}$ in an Eppendorf centrifuge. The supernatants were then washed several times with ethyl ether to remove TCA and evaporated under a nitrogen stream. After this extensive protease treatment most of the glycopeptides have only one amino acid attached to the reducing end of their oligosaccharides (Yamashita et al., 1978). Glycopeptides labelled with $\left[{ }^{14} \mathrm{C}\right.$ glucose were subjected to paper electrophoresis in $5 \%(\mathrm{v} / \mathrm{v})$ formic acid and labelled cations were eluted from the papers with water and chromatographed on Bio-Gel P4 columns.

\section{RESULTS}

\section{Characterization of cellular glucans}

B. ovis REO198 and B. abortus S19 cells were treated with $10 \%$ TCA. As shown in Fig. 1, TCA extracts from $B$. ovis and $B$. abortus contained anthrone-positive compounds that eluted from a Bio-Gel P4 column with an elution volume similar to cyclic $1,2-\beta$-glucans formed in vitro by inner membranes of $R$. meliloti or $A$. tumefaciens. These products (fractions 10-20, Fig. 1) yielded, after total acid hydrolysis and paper chromatography with solvent A, glucose as the only monosaccharide, indicating that they were glucans. Partial acid hydrolysis and paper chromatography with solvent $\mathrm{B}$ yielded glucose, sophorose and a series of oligosaccharides with an increasing degree of polymerization, indicating that these products were 1,2- $\beta$-glucans. These results showed that $B$. ovis and the attenuated strain $\mathrm{S} 19$ of $B$. abortus, contained cellular 1,2- $\beta$-glucans. DEAESephadex chromatography of $B$. ovis and B. abortus S19 cellular glucans showed that approximately $60 \%$ of them were recovered in the percolate and $40 \%$ eluted from the column with $50-500 \mathrm{mM} \mathrm{NaCl}$, indicating that

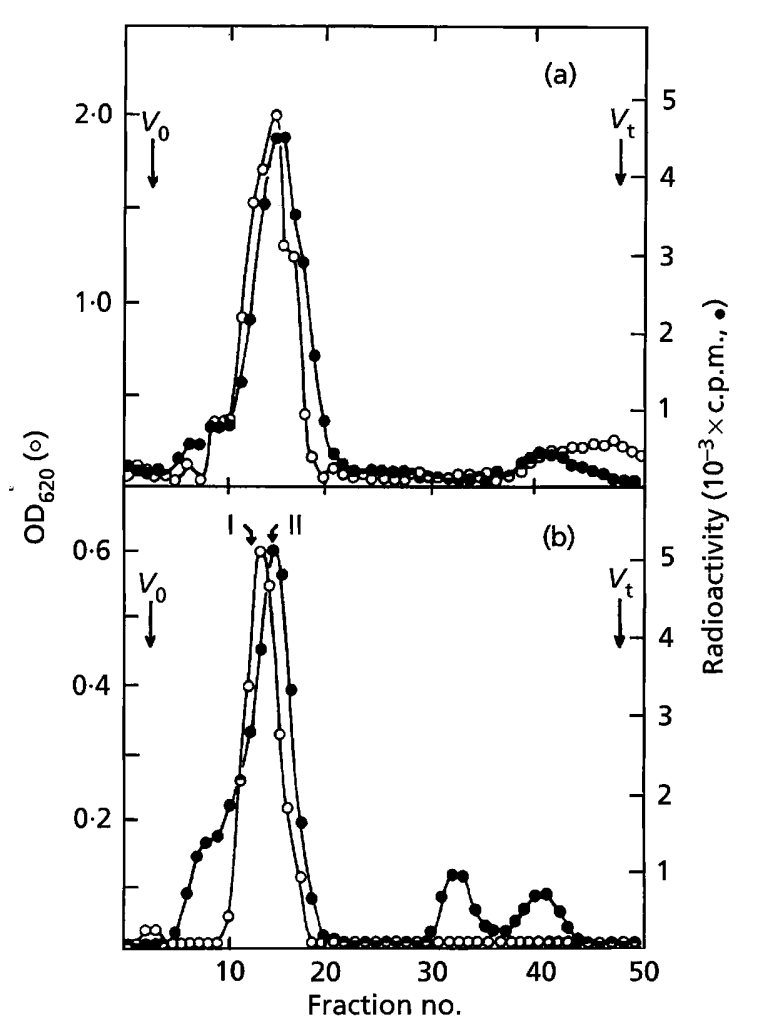

Fig. 1. Bio-Gel P4 chromatography of $B$. ovis REO198 (a) and $B$. abortus $\mathrm{S} 19$ (b) 1,2- $\beta$-glucans. 1,2- $\beta$-glucans formed in vitro; $0,1,2-\beta$-glucans accumulated in vivo; $v_{0}$, void volume; $v_{t}$, total volume; I and II, elution positions of cyclic 1,2- $\beta$-glucans formed in vitro by $R$. meliloti and $A$. tumefaciens, respectively. The BioGel P4 column $(78 \mathrm{~cm} \times 1.8 \mathrm{~cm})$ was eluted with pyridine acetate buffer, $\mathrm{pH} 5.5$, fractions of $1.5 \mathrm{ml}$ were collected and carbohydrates and radioactivity were determined.

they produce neutral and anionic cellular 1,2- $\beta$-glucans (data not shown).

\section{Effect of osmolarity on glucan accumulation}

It was previously shown that A. tumefaciens and $R$. meliloti cells grown in media of high osmolarity $(0.5 \mathrm{M}$ mannitol, $0.5 \mathrm{M}$ glucose or $0.25 \mathrm{M} \mathrm{NaCl}$ ) displayed strong inhibition of the accumulation of cellular cyclic 1,2- $\beta$-glucans (Miller et al., 1986; Zorreguieta et al., 1990). As shown in Table 1 , the accumulation of $B$. ovis cellular glucans was not reduced when cells were grown in the presence of $0.5 \mathrm{M}$ mannitol or $0.5 \mathrm{M}$ glucose. On the contrary, an increase was observed. When cells were grown in $0.25 \mathrm{M} \mathrm{NaCl}$, a condition under which Brucella grows very poorly, inhibition was observed. However, it was not statistically significant. No inhibition of the accumulation of cellular glucan was observed when B. abortus S19 was grown in the presence of the $0.5 \mathrm{M}$ mannitol (Table 1).

\section{Subcellular localization of $1,2-\boldsymbol{\beta}$-glucan}

To determine the subcellular localization of $1,2-\beta$ glucans in Brucella, B. ovis and B. abortus S19 cells were 
Table 1. Effect of osmolarity on the accumulation of cellular cyclic 1,2- $\beta$-glucan in Brucella spp.

Cells were grown in BBS or BB medium as described in Methods.

\begin{tabular}{|llc|}
\hline Strain & \multicolumn{1}{c|}{ Addition } & Cellular glucan* \\
\hline B. ovis REO198 & None & $10 \cdot 7$ \\
& Mannitol $(0.5 \mathrm{M})$ & $18 \cdot 8$ \\
& Glucose $(0 \cdot 5 \mathrm{M})$ & $17 \cdot 6$ \\
& NaCl $(0 \cdot 25 \mathrm{M})$ & $8 \cdot 8$ \\
B. abortus S19 & None & $22 \cdot 7$ \\
& Mannitol $(0.5 \mathrm{M})$ & $22 \cdot 4$ \\
\hline
\end{tabular}

* Cellular glucans [ $\mu \mathrm{mol}$ glucose $(\mathrm{g} \text { cell wet } \mathrm{wt})^{-1}$ ] were extracted from cell pellets with $10 \%$ TCA and extracts subjected to Bio-Gel P4 chromatography. Experiments were repeated twice with a dispersion lower than $20 \%$.

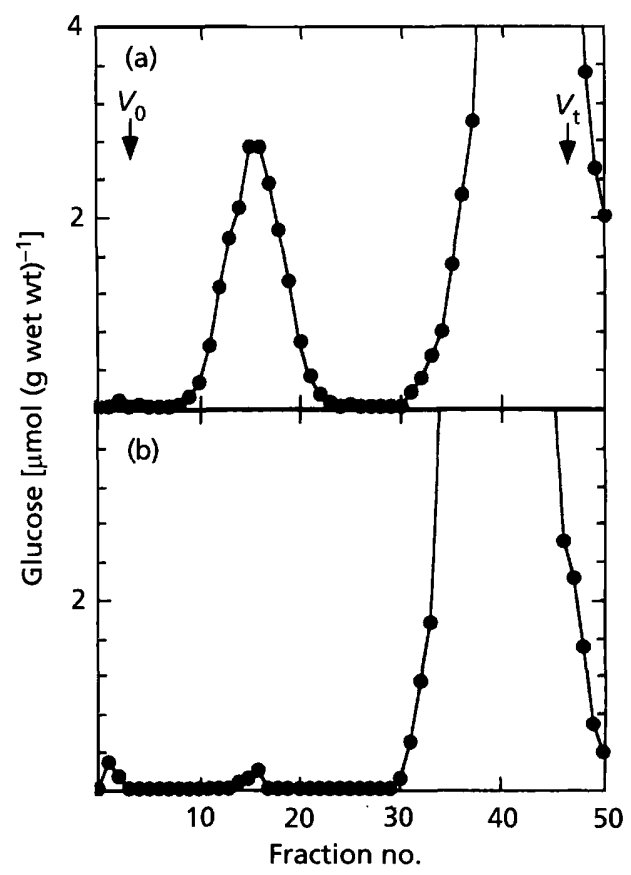

Fig. 2. Subcellular localization of cyclic $1,2-\beta$-glucan in Brucella ovis. Cells were submitted to osmotic shock and the periplasmic fluid was recovered after centrifugation, lyophilized and dissolved in $2 \mathrm{ml}$ water. The remaining pellet was treated with $2 \mathrm{ml} 10 \%$ TCA. The periplasmic fluid (a) and the TCA extract (b) were submitted to gel chromatography. Results are expressed as $\mu \mathrm{mol}$ glucose equivalent ( $\mathrm{g}$ cell pellet wet $w \mathrm{t})^{-1}$.

subjected to osmotic shock. Fig. 2 shows that after such treatment cyclic glucans from $B$. ovis cells were recovered from the periplasmic fluid (Fig. 2a). The remaining cell pellet had no detectable TCA-extractable glucan (Fig. 2b). Assay of the cytoplasmic enzyme malate dehydrogenase detected 0.024 units $\mathrm{ml}^{-1}$ in the total cellular fraction, whereas no activity was detected in the periplasmic fluid. This indicated that the osmotic shock did not produce cellular lysis and that the 1,2- $\beta$-glucans recovered from the periplasmic fluid were not the result of leaking of cytoplasmic fluid into the periplasmic fraction. When B. abortus S19 cells were subjected to osmotic shock, $65 \%$ of the glucan was recovered in the periplasmic fluid; no detectable malate dehydrogenase activity was observed in this fraction.

\section{In vitro biosynthesis of cyclic $1,2-\beta$-glucans}

Incubation of $B$. ovis total membranes with UDP$\left[{ }^{14} \mathrm{C}\right] \mathrm{Glc}$ led to the incorporation of $\left[{ }^{14} \mathrm{C}\right]$ glucose into water-soluble and TCA-insoluble compounds. Watersoluble products recovered in the percolate of DEAESephadex columns were characterized as cyclic $1,2-\beta$ glucans as described below. Total membranes incubated with UDP- $\left[{ }^{14} \mathrm{C}\right] \mathrm{Glc}$ incorporated approximately the same amount of radioactivity into soluble and TCAinsoluble products, 12 and $10 \mathrm{pmol}\left[{ }^{14} \mathrm{C}\right]$ glucose $\mathrm{min}^{-1}$ (mg protein $)^{-1}$, respectively. After a chase with nonlabelled UDP-Glc, TCA-insoluble products did not display the behaviour expected for intermediates, as no reduction in the amount of radioactivity was observed (Fig. 3b, lanes 3 and 4). In contrast, when permeabilized cells were used as enzymic preparation, the radioactivity accumulated in TCA-insoluble products was lower than with total membranes $\left\{4\right.$ pmol $\left[{ }^{14} \mathrm{C}\right]$ glucose $\min ^{-1}(\mathrm{mg}$ protein $\left.)^{-1}\right\}$. Upon the addition of non-labelled UDP-Glc, the insoluble products behaved as intermediates as the label amount decreased (Fig. 4b). In the case of permeabilized cells, the formation of soluble glucans per mg protein was approximately three times higher than with total membranes. PAGE of TCA-insoluble compounds labelled upon incubation of $B$. ovis total membranes (Fig. 3, lanes 3 and 4) and B. ovis permeabilized cells (Fig. 4, lanes 6,7 and 8) with UDP$\left[{ }^{14} \mathrm{C}\right] \mathrm{Glc}$ revealed the presence of proteins with apparent molecular masses indistinguishable from $A$. tumefaciens or $R$. fredii $235 \mathrm{kDa} 1,2-\beta$-glucan intermediate proteins (Fig. 3, lanes 1, 2, 5 and 6). It can be observed that after the addition of non-labelled UDP-Glc, labelled proteins formed by membranes of $A$. tumefaciens or $R$. fredii (Fig. 3, lanes 1, 2 and 5,6) or permeabilized cells of $B$. ovis (Fig. 4, lanes 6,7 and 8) and B. abortus (Fig. 4, lanes 3,4 and 5) behaved as intermediates, with a rapid reduction in radioactivity. Fig. 3 shows that $B$. ovis membranes contained, besides the $235 \mathrm{kDa}$ protein, at least two other labelled proteins having lower molecular masses. They probably represent products of proteolytic degradation since their relative amounts changed in different membrane preparations. After the addition of non-labelled UDP-Glc $(2 \mathrm{mM})$, an increment of the apparent molecular mass became apparent (Fig. 3b, lanes 3 and 4, and Fig. $6 \mathrm{~b}$ inset). These results suggested that the reaction of cyclization, that under normal circumstances releases cyclic glucan from the intermediate protein, proceeded less efficiently in vitro with membranes; moreover it seems to be completely blocked upon chasing with $2 \mathrm{mM}$ UDP-Glc. It may be assumed that this defective cyclization led, upon addition of $2 \mathrm{mM}$ UDP-Glc, to uncontrolled elongation and conse- 
(a)

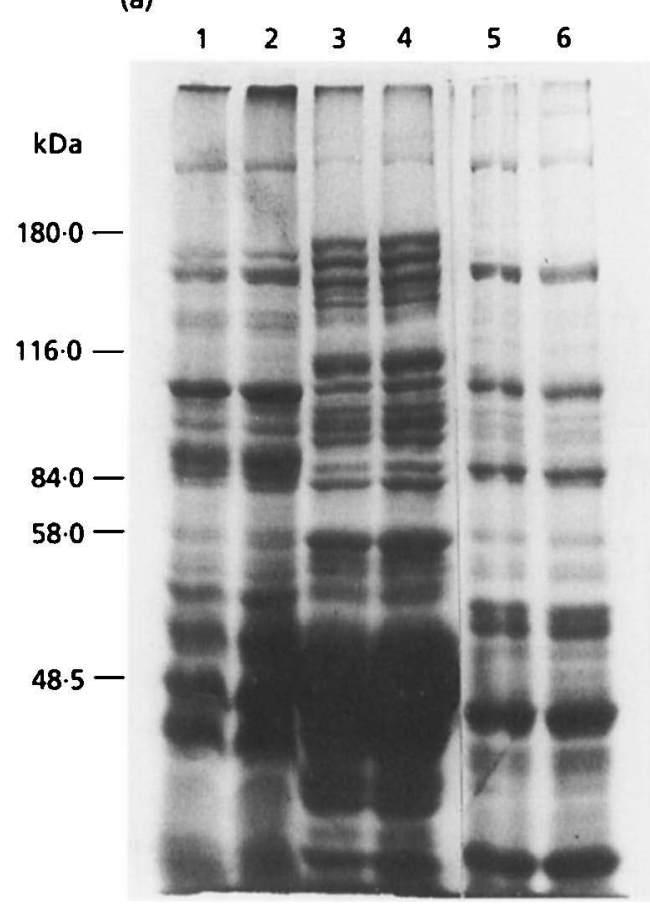

(b)

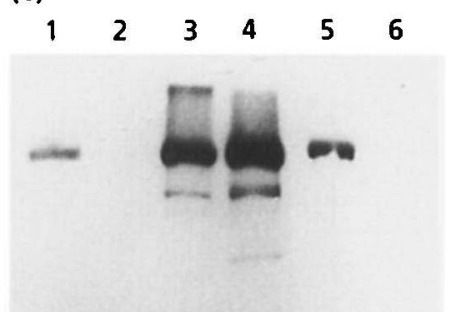

Fig. 3. PAGE of membranes incubated with UDP- $\left[{ }^{14} \mathrm{C}\right] \mathrm{Glc}$. Total membranes $(0.2 \mathrm{mg}$ protein) of B. ovis strain REO198 (lanes 3 and 4 ) or inner membranes $(0.2 \mathrm{mg}$ protein) of $A$. tumefaciens A348 (lanes 1 and 2) or $R$. fredii USDA191 (lanes 5 and 6) were incubated with UDP- $\left[{ }^{14} \mathrm{C}\right] \mathrm{Glc}$, the reactions were stopped by the addition of $10 \%$ TCA and the precipitates were subjected to gel electrophoresis. Proteins were stained with Coomassie blue (a) and radioactivity, detected by fluorography (b). For the chase experiment (even-numbered lanes), $2 \mathrm{mM}$ non-radioactive UDP-Gle was added after a $10 \mathrm{~min}$ incubation and the reactions were stopped after $30 \mathrm{~min}$. Numbers on the right indicate the molecular masses of standards.

(a)

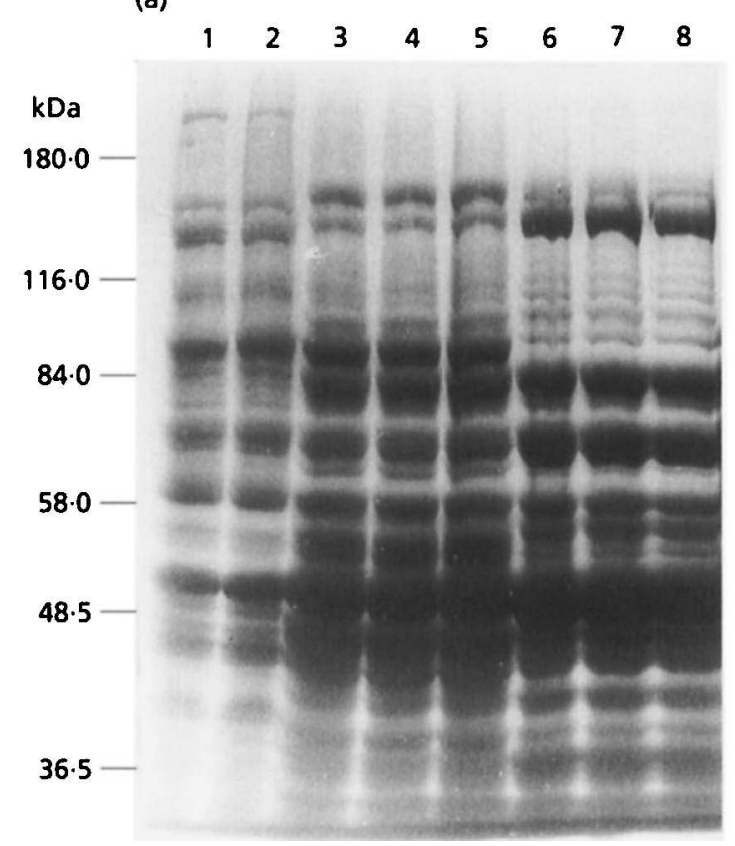

(b)

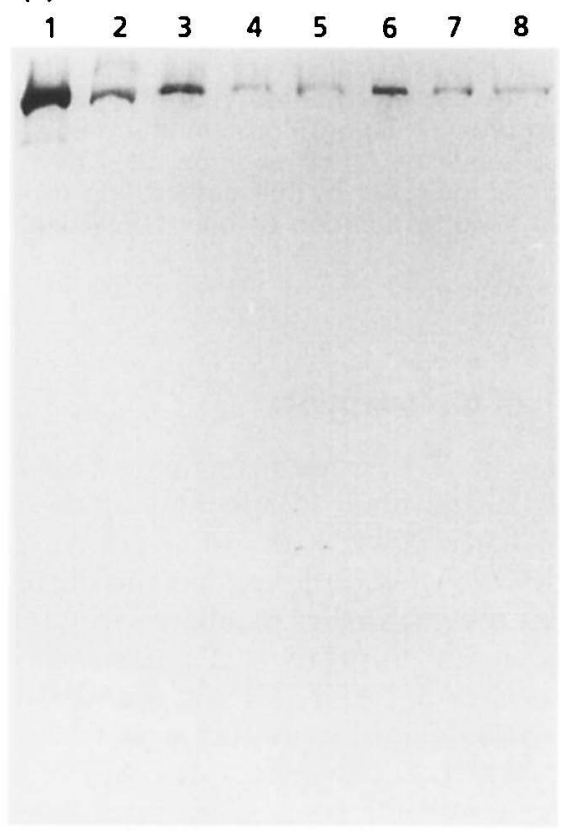

Fig. 4. PAGE of total membranes and permeabilized cells incubated with UDP- $\left[{ }^{14} \mathrm{C}\right] \mathrm{GIc}$. Lanes: 1 and 2 , inner membranes $(0.2 \mathrm{mg}$ protein) of $A$. tumefaciens A348; 3,4 and 5 , permeabilized cells $(0.2 \mathrm{mg}$ protein) of $B$. abortus $S 19 ; 6,7$ and 8 permeabilized cells $\left(0.2 \mathrm{mg}\right.$ protein) of $B$. ovis REO198; 1,3 and 6,10 min incubation with UDP- $\left[{ }^{14} C\right] G I c ; 2,4$ and 7 , chase experiment in which, after $10 \mathrm{~min}$ incubation with UDP- $\left[{ }^{14} \mathrm{C}\right] \mathrm{Glc}, 2 \mathrm{mM}$ non-radioactive UDP-Glc was added and the incubations were continued for $30 \mathrm{~min} ; 5$ and 8 , chase experiment with $20 \mathrm{mM}$ UDP-Glc. Proteins were stained with Coomassie blue (a) and radioactivity, detected by fluorography (b).

quently to the accumulation of protein intermediates with larger than normal linear oligosaccharides that cannot be cyclized (see below). The kinetics of in- corporation of $\left[{ }^{14} \mathrm{C}\right]$ glucose into soluble glucan and intermediate protein by permeabilized cells are shown in Fig. 5 . 


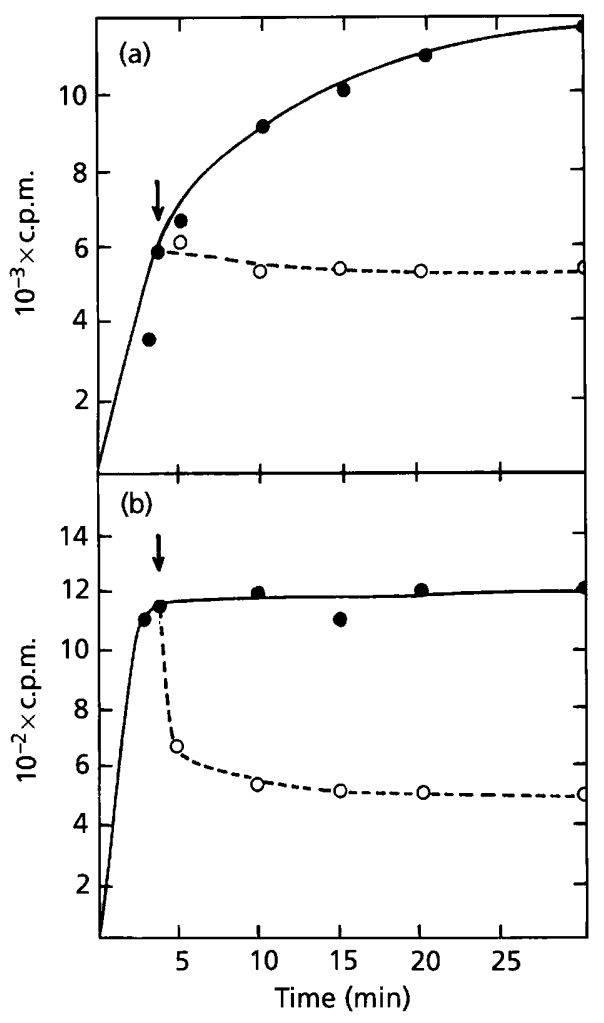

Fig. 5. 1,2- $\beta$-Glucan synthesis by permeabilized cells of $B$. ovis. Permeabilized cells of $B$. ovis REO198 were incubated with UDP$\left[{ }^{14} \mathrm{C}\right] \mathrm{Glc}$. The graphs $(0)$ show incorporation of $\left[{ }^{14} \mathrm{C}\right]$ glucose into $1,2-\beta$-glucan (a) and into 1,2- $\beta$-glucan protein intermediate (b). Incorporation of $\left[{ }^{14} \mathrm{C}\right]$ glucose after addition of $2 \mathrm{mM}$ nonradioactive UDP-GIC is indicated by the dashed line $(O)$. The arrows indicate the time of addition of non-radioactive UDPGlc.

\section{Characterization of glycopeptides}

Total membranes of $B$. ovis were incubated at $37^{\circ} \mathrm{C}$ with UDP- $\left[{ }^{14} \mathrm{C}\right] \mathrm{Glc}$ and after $15 \mathrm{~min}$ half of the total incubation was inactivated with $10 \%$ TCA; nonlabelled UDP-Glc $(2 \mathrm{mM})$ was then added and the rest of the reaction mixture was further incubated for $20 \mathrm{~min}$. One-tenth aliquots (200 $\mu$ g protein) of pulse and chase samples were subjected to PAGE (Fig. 6b, inset); the rest of the samples were subjected to extensive proteolysis to generate pulse and chase glycopeptides which were purified by paper electrophoresis. Glycopeptides were eluted from the paper strips with water and subjected to Bio-Gel P4 chromatography to estimate their degree of polymerization. The pulse incubation with $0.02 \mathrm{mM}$ UDP- $\left[{ }^{14} \mathrm{C}\right]$ Glc yielded glycopeptides that eluted from the Bio-Gel P4 columns with elution volumes slightly higher than $B$. ovis 1,2- $\beta$-glucans obtained in vitro (Fig. $6 \mathrm{a}$ and $\mathrm{c}$ ). After a chase with $2 \mathrm{mM}$ UDP-Glc, glycopeptides appeared in the void volumes of the Bio-Gel P4 columns (Fig. 6b), indicating that they had a higher degree of polymerization. PAGE of pulse and chase TCA-insoluble products revealed the presence of $\left[{ }^{14} \mathrm{C}\right]$ glucose-labelled proteins with similar amounts of

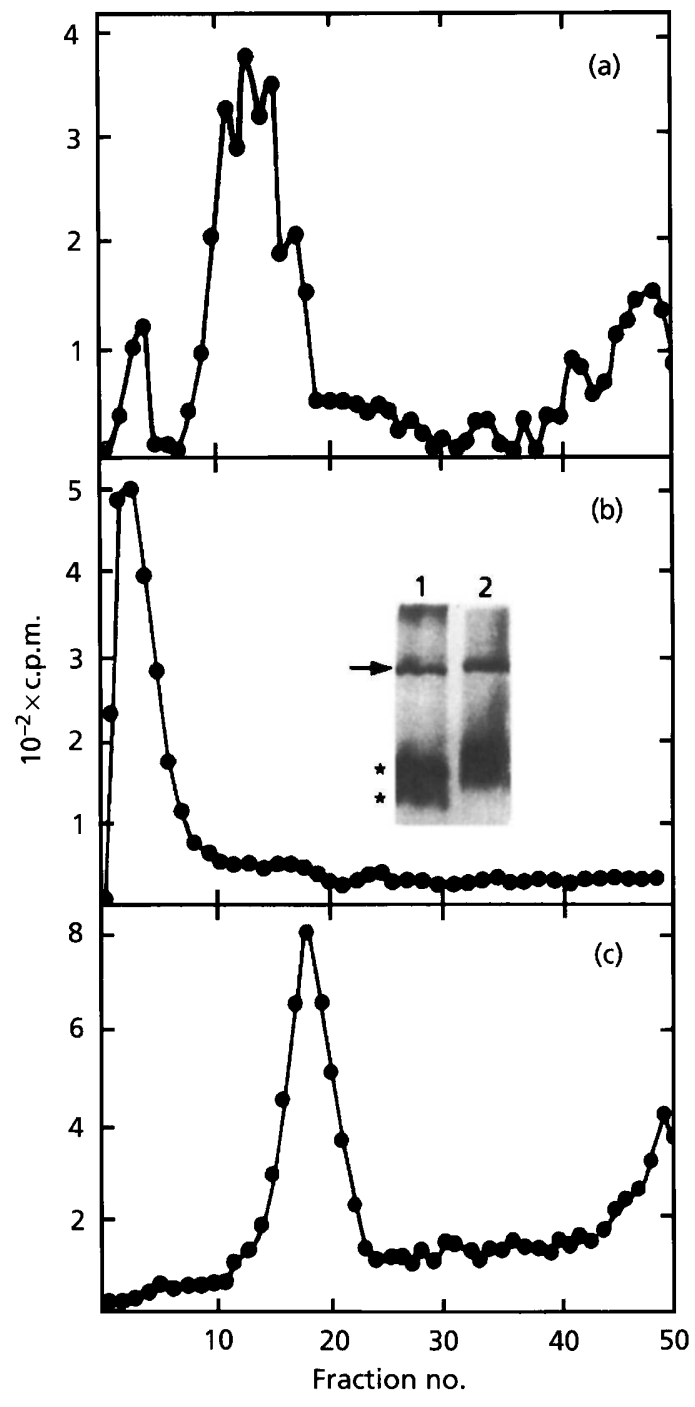

Fig. 6. Bio-Gel P4 chromatography of B. ovis REO198 $\left[{ }^{14} \mathrm{C}\right]$ glucose-labelled glycopeptides. $\left[{ }^{14} \mathrm{C}\right] \mathrm{Glucose}$-labelled peptides were obtained and purified as described in Methods. Total membranes were incubated with UDP- $\left[{ }^{14} \mathrm{C}\right] \mathrm{Glc}$ for $10 \mathrm{~min}$ (pulse-glycopeptides, a); after $10 \mathrm{~min}$ incubation with UDP$\left[{ }^{14} \mathrm{C}\right] \mathrm{Glc}, 2 \mathrm{mM}$ non-radioactive UDP-Glc was added and the incubation was continued for $30 \mathrm{~min}$ (chase-glycopeptides, b). (c) Cyclic 1,2- $\beta$-glucan obtained in vitro from total membranes of $B$. ovis REO198. The inset in (b) shows PAGE of TCA precipitates of pulse (lane 1) and pulse-chase samples (lane 2); the arrow indicates the position of the $235 \mathrm{kDa}$ intermediate protein of $A$. tumefaciens A 348 and the asterisks indicate degradation products of the intermediate protein.

radioactivity. The chase-derived species showed an increment in their apparent molecular masses (Fig. 6b inset, lane 2). Pulse and chase experiments carried out with $B$. abortus total membranes showed similar behaviour (data not shown). It was thus concluded that Brucella membranes do not control the elongation reaction when a relatively high concentration of UDPGlc $(2 \mathrm{mM})$ is added to the reaction mixture. As a consequence of this, intermediate proteins with oligo- 


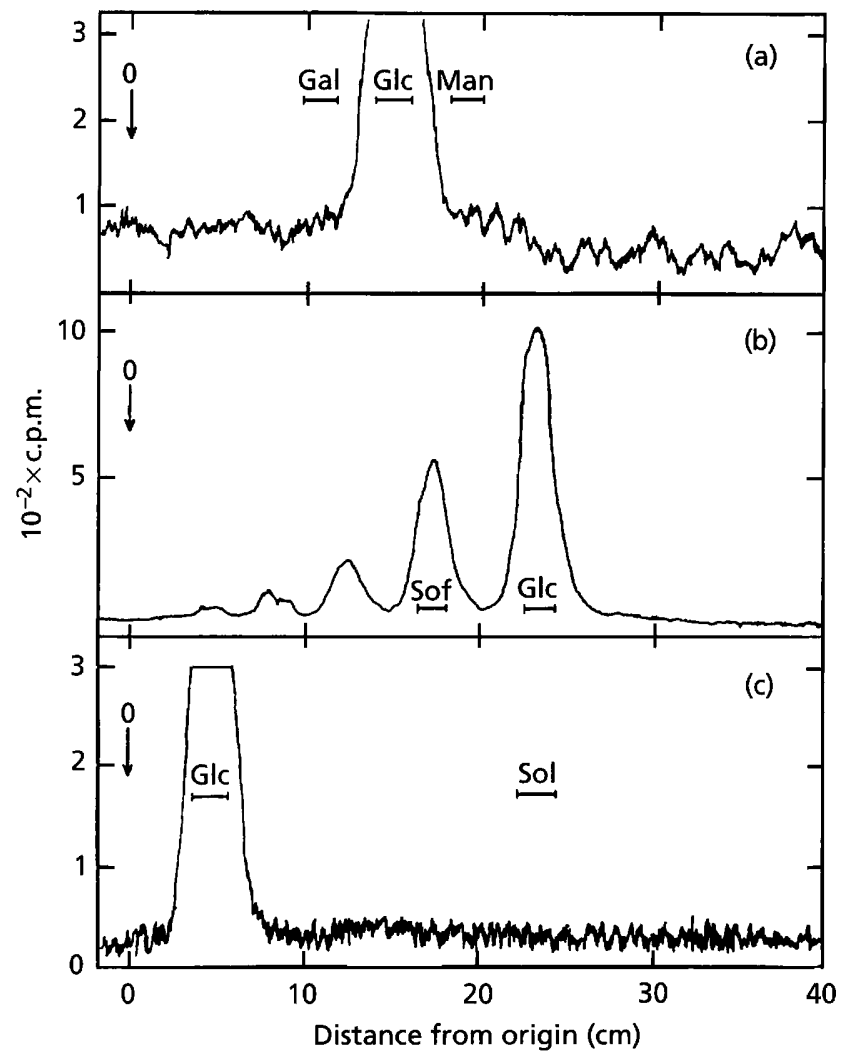

Fig. 7. Characterization of cyclic $1,2-\beta$-glucan formed in vitro. In vitro synthesis of cyclic $1,2-\beta$-glucan was carried out with total membranes of $B$. ovis REO198. Glucan was purified by Bio-Gel P4 chromatography and subjected to total and partial acid hydrolysis and reduction with sodium borohydride. (a) Paper chromatography of total acid hydrolysis products developed with solvent $A_{i}$ (b) paper chromatography of partial acid hydrolysis products developed with solvent B; (c) paper electrophoresis with buffer $\mathrm{C}$ ( $2 \%$ sodium molybdate, $\mathrm{pH} 5.0)$. Standards: Gal, galactose; Glc, glucose; Man, mannose; Sof, sophorose; Sol, sorbitol.

saccharides having a high degree of polymerization are accumulated, resulting in impeded cyclization.

\section{Characterization of $1,2-\beta$-glucan formed in vitro}

Water-soluble compounds formed after incubation of total membranes with UDP- $\left[{ }^{14} \mathrm{C}\right]$ Glc eluted from a BioGel P4 column as two main products (Fig. 1). The most abundant product (fractions 10-20) had approximately the same elution volume of in vivo-formed cellular 1,2$\beta$-glucans. Compounds eluting from the column close to the total volume were not characterized. Neutral glucans from $B$. ovis recovered from Bio-Gel P4 columns (fractions 10-20) were subjected to total and partial hydrolysis and products subjected to paper chromatography. As shown in Fig. 7(a), $\left[{ }^{14} \mathrm{C}\right]$ glucose was the only monosaccharide recovered after total acid hydrolysis and paper chromatography with buffer A. $\left[{ }^{14} \mathrm{C}\right]$ Glucose, $\left[{ }^{14} \mathrm{C}\right]$ sophorose and a series of ${ }^{14} \mathrm{C}$-labelled oligosaccharides with increasing degree of polymerization were recovered after partial acid hydrolysis and paper chromatography in buffer B (Fig. 7b). To determine if these $1,2-\beta$-glucans formed in vitro were cyclic molecules, 60000 c.p.m. of glucan recovered from the Bio-Gel P4 column (fractions 10-20) was subjected to sodium borohydride reduction, total acid hydrolysis and paper electrophoresis. As shown in Fig. 7(c), no sorbitol was detected after paper electrophoresis with buffer C. The same result was obtained with glucans formed by total membranes of $B$. abortus $S 19$. These results showed that total membranes of $B$. ovis and B. abortus formed cyclic 1,2- $\beta$-glucan in vitro. Cyclic 1,2- $\beta$-glucans formed in vitro eluted from a Bio-Gel P4 column at an approximately similar elution volume as the cellular glucan accumulated in vivo, suggesting that they had the same degree of polymerization (Fig. 1). TLC of cyclic $1,2-\beta$-glucans formed in vitro by $B$. ovis permeabilized cells and A.tumefaciens inner membranes revealed that they had the same size distribution and degree of polymerization (Fig. 8a and b). In contrast, B. ovis total membranes formed 1,2- $\beta$-glucans in vitro with a size distribution displaced toward a higher degree of polymerization than glucans formed by permeabilized cells and similar to cyclic 1,2- $\beta$-glucans formed by $R$. melilot $i$ and $R$. fredii (Fig. 8a, $\mathrm{d}$ and $\mathrm{e}$ ).

\section{DISCUSSION}

Our results show that the rough strain of $B$. ovis REO198 and the attenuated vaccine strain $B$. abortus S19 contain, as described for B. melitensis (Bundle et al., 1987 ) and a pathogenic strain of B. abortus (Bundle et al., 1988), cyclic $1,2-\beta$-glucans. Osmotic shock studies established that B. ovis REO198 and B. abortus S19 glucans are mainly accumulated in the periplasmic space. Since it was observed that $B$. ovis is more sensitive than $B$. abortus to the zwittergent-lysozyme extraction method, a modification of the original method was used to study glucan cellular localization in this strain. The results reported here suggest the presence in Brucella of a functional secretory pathway for cyclic $1,2-\beta$-glucans as described in Agrobacterium and Rhizobium. In these species, cyclic glucans are synthesized in the cytoplasm by a membrane-bound enzyme and secreted into the periplasmic space.

The biosynthesis of cyclic glucans in Agrobacterium and Rhizobium proceeds through a novel mechanism in which a protein participates as intermediate (Zorreguieta \& Ugalde, 1986). Glucose units are transferred from UDP-Glc to an inner-membrane protein with an apparent molecular mass of $235 \mathrm{kDa}$, until the $1,2-\beta$-glucan formed has about $17-24$ glucose residues. The glucan is then released from the protein as a cyclic molecule secreted into the periplasmic space by a secretory system in which $\mathrm{NdvA}$ or ChvA proteins participate. Indirect evidence supports the notion that initiation, elongation and cyclization reactions are catalysed by the $235 \mathrm{kDa}$ protein (Altabe et al., 1990). 
(a)

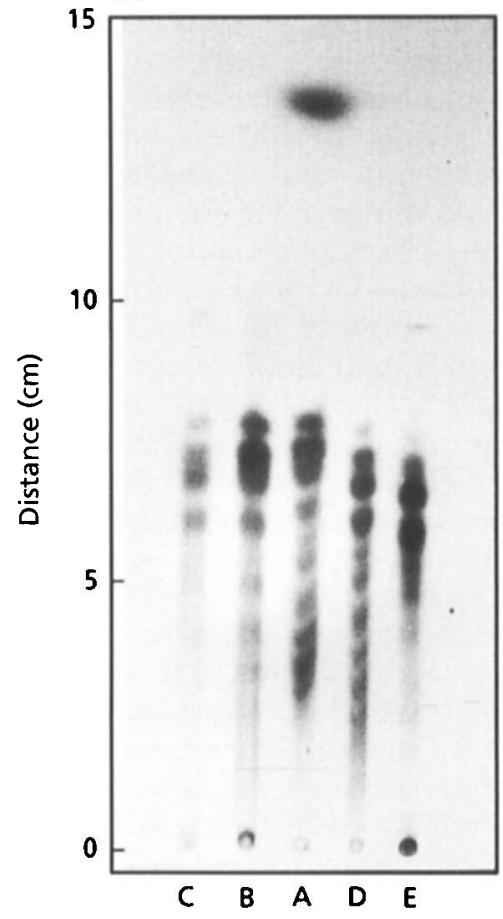

(b)

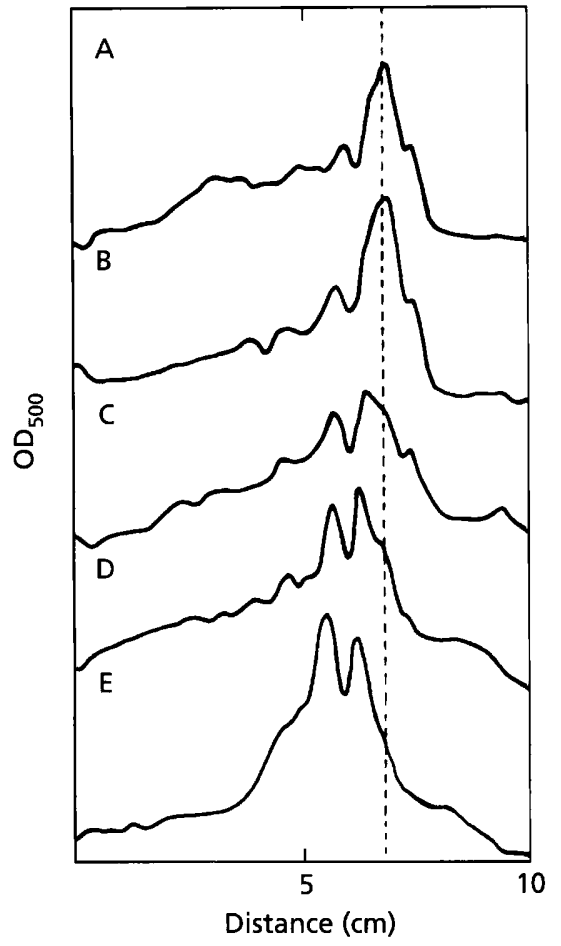

Fig. 8. TLC of cyclic 1,2- $\beta$-glucans obtained in vitro. Lanes: $A$, inner membranes of $A$. tumefaciens; $B$, permeabilized cells of $B$. ovis; C, total membranes of B. ovis; D and $E$, inner membranes of $R$. meliloti and $R$. fredii, respectively. (a) Autoradiograph; (b) densitometric scanning of autoradiographs. The autoradiograph of the plate was scanned using a Gilford Response II spectrophotometer with an autoradiograph holder accessory at $500 \mathrm{~nm}$.
We describe here that in Brucella spp. the biosynthesis of cyclic 1,2- $\beta$-glucans proceeds as in Agrobacterium and Rhizobium through an intermediate membrane protein with an apparent molecular mass indistinguishable from the $235 \mathrm{kDa}$ protein of $A$. tumefaciens. The in vitro kinetic behaviour of the Brucella protein intermediate was very different to that observed with Agrobacterium or Rhizobium. In Brucella, membrane preparations displayed defective synthesis in vitro characterized by an impaired cyclization and uncontrolled elongation when a relatively high concentration of UDP-Glc $(2 \mathrm{mM})$ is added to the reaction mixture. The same behaviour was observed when the Brucella $235 \mathrm{kDa}$ protein was expressed in a R. meliloti $n d v B$ mutant (Iñón de Iannino et al., 1996) or a A.tumefaciens chvB mutant (N. Iñón de Iannino and others, unpublished). When Nonidet P40permeabilized cells were used as enzymic preparation, the biosynthesis proceeded more efficiently than with total membranes and cyclization was not impeded. These results suggest that a factor(s), that was lost or inactivated during the preparation of membranes, is required in Brucella for the effective regulation between elongation and cyclization reactions involved in the synthesis of cyclic 1,2- $\beta$-glucans. The degree of polymerization of cyclic glucans formed by total membranes or by permeabilized cells was different. The degree of polymerization of glucans formed by total membranes was higher than permeabilized cell glucans.

A. tumefaciens and R. meliloti cells grown in media of high osmolarity display a strong inhibition of the accumulation of cellular cyclic 1,2- $\beta$-glucans (Miller et al., 1986; Dylan et al., 1990; Zorreguieta et al., 1990). According to our results, B. ovis and B. abortus cellular cyclic $1,2-\beta$-glucan accumulation is not inhibited by osmolarity as previously described in Agrobacterium and Rhizobium. We conclude that Brucella cyclic glucan biosynthesis is not osmoregulated. This regulation might not be important for a bacterium such as Brucella, which is poorly adapted to survive outside the host and which persists in nature inside the iso-osmotic environment of the host phagocyte cells.

The role of cyclic 1,2- $\beta$-glucan in Brucella is unknown, but the presence of this polysaccharide and its conservation in different genera of the $\alpha 2$ group of Proteobacteriaceae, suggest a possible function in the interaction of bacteria with eukaryotic cells as demonstrated in Agrobacterium and Rhizobium.

\section{ACKNOWLEDGEMENTS}

We thank Susana Raffo for technical assistance and María de los Angeles Curto for the preparation of UDP- $\left[{ }^{14} \mathrm{C}\right] \mathrm{Glc}$. We acknowledge A. J. Parodi for critical revision of the manuscript. G. Briones is a fellow of the Comision Nacional de Energía Atómica, M. Steinberg is a student in the Facultad de Ciencias Exactas y Naturales (UBA), and N. Iñón de Iannino and R. A. Ugalde are members of the Consejo National de Investigaciones Científicas y Técnicas (CONICET), Argentina. 


\section{REFERENCES}

Abe, A., Amemura, A. \& Higashi, S. (1982). Studies on cyclic $\beta(1-$ 2) glucan obtained from periplasmic space of Rhizobium trifolii cells. Plant Soil 64, 315-324.

Altabe, S., Iñón de lannino, N., de Mendoza, D. \& Ugalde, R. A. (1990). Expression of the Agrobacterium tumefaciens chvB virulence region in Azospirillum spp. J Bacteriol 172, 2563-2567.

Bundle, D. R., Cherwonogrodzky, J. W. \& Perry, M. B. (1987). The structure of the lipopolysaccharide $\mathrm{O}$-chain ( $\mathrm{M}$ antigen) and polysaccharide B produced by Brucella melitensis 16M. FEMS Lett 216, 261-264.

Bundle, D. R., Cherwonogrodzky, J. W. \& Perry, M. B. (1988). Characterisation of Brucella polysaccharide B. Infect Immun 56, 1101-1106.

Breedveld, M. W., Zevenhuizen, L. P. T. M. \& Zehnder, A. J. B. (1990). Osmotically induced oligo- and polysaccharide synthesis by Rhizobium meliloti SU-47. J Gen Microbiol 136, 2511-2519.

Cangelosi, G. A., Martinetti, G., Leigh, J. A., Chang Lee, C., Theines, C. \& Nester, E.W. (1989). Role for Agrobacterium tumefaciens ChvA protein in export of $\beta(1-2)$ glucan. J Bacteriol 171, 1609-1615.

Cangelosi, G. A., Martinetti, G. \& Nester, E. W. (1990). Osmosensitivity phenotypes of Agrobacterium tumefaciens mutants that lack periplasmic $\beta$-1,2-glucan. J Bacteriol 172, 2172-2174.

Cherwonogrodzky, J. W., Dubray, G., Moreno, E. \& Mayer, H. (1990). Antigens of Brucella. In Animal Brucellosis, pp. 19-64. Edited by K. Nielsen \& J. R. Duncan. Boca Raton: CRC Press.

De Lay, J., Mannheim, W., Segers, P., Lievens, A., Denijn, M., Vanhoucke, M. \& Gillis, M. (1987). Ribosomal ribonucleic acid cistron similarities and taxonomic neighbourhood of Brucella and CDC group Vd. Int J Syst Bacteriol 37, 35-42.

Dische, Z. (1962). General colour reactions. Methods Carbohydr Chem 1, 478-492.

Douglas, C. J., Staneloni, R. J., Rubin, R. A. \& Nester, E. W. (1985). Identification and genetic analysis of an Agrobacterium tumefaciens chromosomal virulence region. J Bacteriol 161, $850-860$.

Dylan, T., lelpi, L., Stanfield, S., Kashyap, L., Douglas, C., Yanofsky, M., Nester, E. W., Helinski, D. R. \& Ditta, G. (1986). Rhizobium meliloti genes required for nodule development are related to chromosomal virulence genes in Agrobacterium tumefaciens. Proc Natl Acad Sci USA 83, 4403-4407.

Dylan, T., Helinski, D. R. \& Ditta, G. S. (1990). Hypoosmotic adaptation in Rhizobium meliloti requires $\beta(1-2)$ glucan. $J$ Bacteriol 172, 1400-1408.

Finan, T. M., Hirsch, A. M., Leigh, J. A., Johansen, E. J., Kuldau, G. A., Deegan, S., Walker, G. C. \& Signer, E. R. (1985). Symbiotic mutants of Rbizobium meliloti that uncouple plant from bacterial differentiation. Cell 40, 869-877.

Geremia, R. A., Cavaignac, S., Zorreguieta, A., Toro, N., Olivares, J. \& Ugalde, R. A. (1987). A Rhizobium meliloti mutant that forms ineffective pseudonodules in alfalfa produces exopolysaccharide but fails to form $\beta(1-2)$ glucan. J Bacteriol 169, 880-884.

Hisamatsu, M., Amemura, A., Koizumi, K., Utamura, T. \& Okada, Y. (1983). Structural studies on cyclic(1-2)-beta-D-glucans (cyclosophoraose) produced by Agrobacterium and Rhizobium. Carbohydr Res 121, 31-40.

Iñón de lannino, N. \& Ugalde, R. A. (1989). Biochemical characterization of avirulent Agrobacterium tumefaciens chvA mutants : synthesis and excretion of $\beta(1-2)$ glucan. $J$ Bacteriol 171, 2842-2849.
Iñón de lannino, N. \& Ugalde, R. A. (1993). Biosynthesis of cyclic $\beta(1-3), \beta(1-6)$ glucan in Bradyrhizobium spp. Arch Microbiol 159, $30-38$.

Iñón de lannino, N., Briones, G., Tolmasky, M. E. \& Ugalde, R. A. (1996). Molecular cloning of a Brucella abortus gene that complements an $n d v B$ deficient mutant of Rhizobium meliloti. In Abstracts of the 96th ASM General Meeting, New Orleans, Louisiana, USA, 19-23 May 1996.

Leigh, J., Signer, E. R. \& Walker, G. C. (1985). Exopolysaccharidedeficient mutants of Rhizobium meliloti that form ineffective nodules. Proc Natl Acad Sci USA 82, 6231-6235.

Miller, K. J., Kennedy, E. P. \& Reinhold, V. N. (1986). Osmotic adaptation by Gram-negative bacteria: possible role for periplasmic oligosaccharides. Science 231, 48-51.

Moreno, E., Berman, D. T. \& Boetcher, L. A. (1981a). Biological activities of Brucella abortus lipopolysaccharides. Infect Immun 31, 362-370.

Moreno, E., Speth, S. L., Jones, L. M. \& Berman, D. T. (1981b). Immunochemical characterization of Brucella lipopolysaccharides and polysaccharides. Infect Immun 31, 214-222.

Moriyon, I. \& Berman, D. T. (1982). Effects of nonionic, ionic, and dipolar ionic detergents and EDTA on the Brucella cell envelope. $J$ Bacteriol 152, 822-828.

Puvanesarajah, V., Schell, F. M., Stacey, G., Douglas, C. J. \& Nester, E. W. (1985). Role for 2-linked $\beta$-D-glucan in the virulence of Agrobacterium tumefaciens. J Bacteriol 164, 102-106.

Reeves, P. (1995). Role of O-antigen variation in the immune response. Trends Microbiol 3, 381-385.

Smith, L. D. \& Ficht, T. A. (1990). Pathogenesis of Brucella. Crit Rev Microbiol 17, 209-229.

Stabel, T. J., Sha, Z. \& Mayfield, J. (1994). Periplasmic location of Brucella abortus $\mathrm{Cu} / \mathrm{Zn}$ superoxide dismutase. Vet Microbiol 38, 307-314.

Triplett, E. W., Breil, B. T. \& Splitter, G. A. (1994). Expression of $t f x$ and sensitivity to the rhizobial peptide antibiotic trifolitoxin in a taxonomically distinct group of $\alpha$-Proteobacteria including the animal pathogen Brucella abortus. Appl Environ Microbiol 60, 4163-4166.

Tully, R. E., Keister, D. L. \& Gross, K. C. (1990). Fractionation of the $\beta$-linked glucans of Bradyrhizobium japonicum and their response to osmotic potential. Appl Environ Microbiol 56, 1518-1522.

Whatley, M. H., Bodwin, J. S., Lippincott, B. B. \& Lippincott, J. A. (1976). Role for Agrobacterium cell envelope lipopolysaccharide in infection site attachment. Infect Immun 13, 1080-1083.

Williamson, G., Damani, K., Devenney, P., Faulds, C. B., Morris, V. J. \& Stevens, B. J. H. (1992). Mechanism of action of cyclic $\beta(1-2)-$ glucan synthetase from Agrobacterium tumefaciens: competition between cyclization and elongation reactions. J Bacteriol 174, 7941-7947.

Worthington Diagnostic Systems, Inc. (1982). Worthington Enzyme Manual. Freehold, NJ: Worthington Diagnostic Laboratories.

Yamashita, K., Tachibana, Y. \& Kobata, A. (1978). The structures of the galactose-containing sugar chains of ovalbumin. $J$ Biol Chem 253, 3862-3869.

York, W. S., McNeil, M., Darvill, A. G. \& Albersheim, P. (1978). Beta-2-linked glucans secreted by fast-growing species of $\mathrm{Rh}$ zobium. J Bacteriol 142, 243-248.

Zevenhuizen, L. P. T. M. \& van Neerven, A. R. W. (1983). (1-2)- $\beta$ - 
D-Glucan and acyclic oligosaccharides produced by Rhizobium meliloti. Carbohydr Res 118, 127-134.

Zevenhuizen, L. P. T. M., van Veldhuizen, A. \& Fokkens, R. H. (1990). Re-examination of cellular cyclic $\beta$-1,2-glucans of Rhizobiaceae: distribution of ring sizes and degrees of glycerol-1-phosphate substitution. Antonie Leeuwenboek 57, 173-178.

Zorreguieta, A. \& Ugalde, R. A. (1986). Formation in Rhizobium and Agrobacterium spp. of a 235 -kilodalton protein intermediate in $\beta$ - $\mathrm{D}(1,2)$ glucan synthesis. J Bacteriol 167, 947-951.

Zorreguieta, A., Cavaignac, S., Geremia, R. A. \& Ugalde, R. A. (1990). Osmotic regulation of $\beta(1-2)$ glucan synthesis in members of the family Rhizobiaceae. J Bacteriol 172, 4701-4704.

Received 5 August 1996; revised 4 November 1996; accepted 3 December 1996. 